\title{
Are padang city branding shaping audience consciousness: an semiotics analysis of three padang city branding
}

\author{
Fitri Adona ${ }^{1}$, Yusnani $^{2}$, Sri Nita ${ }^{3}$ \\ ${ }^{123}$ Politeknik Negeri Padang, Kampus Limau Manis \\ E-mail:fitriadona@yahoo.com
}

\begin{abstract}
One form of city marketing that is currently developing is the provision of city image or city branding. Brands can have 6 levels of understanding namely attributes, benefits, cultural values, personality, and users. Cultural values are very different, especially around socially embedded issues such as status, gender, family, ethics, and customs. City branding helps influence "transfer of value" by establishing a relationship between what culture sees as a desired city and a particular product. This research is a study of the city branding of Padang city or a brand that is considered to belong to Padang City, namely "Padang Your Motherland", "Serenity of Minangkabau", and "Padang Taste". To what extent does three brand of padang city influence consumer awareness of the values of Minangkabau culture that is dominantly adopted by the people of Padang City? Semiotic analysis and personal interviews were used to answer this research question. Some consumers are less aware of the commercial objectives of these three city branding. They don't seem to know much about the intentions of city branding makers "to play with their consciousness".
\end{abstract}

Keywords_ city branding; values; culture; semiotics; Padang

\section{INTRODUCTION}

Muge Riza wrote in 2015,

"City branding strategies are used as a tool to race with other cities by displaying appealing images of the city and its assets. In this context, culture is as a marketable strength and new opportunity for cities to increasingly gain popularity"

The above-mentioned quotation tells of the pervasiveness of utilization of cultural as a branding device. It discusses the role of culture in city branding and compares the use of recent popular tools, namely large-scale events, festivals and iconic architecture as a means for branding purpose.

Kavaratzis, M. And Ashworth, G.J. (2015) wrote about the the dominant understanding of culture within place branding is inadequate and leads to disconnection between local culture and the place brand. The article discusses significant tensions arising from an evident oversimplification of the relationship between place brands and culture. This relationship is reconstructed through a reappreciation of its complexity and reciprocity. The article provides a refined appreciation of the role of place brands in the production of culture as well as of the cultural nature of place brands and explores the implications of such thinking. Synergies are found in clarifying the formation and function of place brands as cultural phenomena, and, particularly, in understanding the link that culture provides between locals, their place and its brand.

Values are simply property of objects, individuals, institutions, toward which people have an affective regard (Sivaram 1991). Rokeach (1973) defines values as:

"A value is an enduring belief that a specific mode of or end state of existence is personally or socially preferable to an opposite or converse mode of 
conduct or end state of existence. A value system is an enduring organizations of beliefs concerning preferable modes of conduct or end states of existence along a continuum of relative importance."

Thus, values are very important determinants of behaviour, both in personal and social life. They are the co-ordinates of virtually all kinds of human interaction (Sivaram 1991).

Communication is used to optimalizedthe interaction between regional government and investor so that create the interaction. Through the right communication strategy, the city government can inform the potential of their city to the investor as well. On the other hand, the investor can easily to catch the business opportunities in that city. One of the best communication strategy option is create the city branding communication. In 2008 the city government confirmed "Padang Your Motherland" as the city branding.

Although the branding internal programme "Padang Your Motherland" assessed had not apllied maximally, so that some people especially creative worker of tourism sector unable to respond as well, on 24 November 2017 also appear province tourism branding of West Sumatera "Taste of Padang" which made a prons and cons in the society. That is because branding for 12 regencies and 7 cities in the province seems to be intended for Padang City, even though the inclusion of the word "Padang" in the tagline "the verbal or written part of the city branding that summarizes the objectives and main ideas in a few memorable words" is explained because the people of the archipelago and overseas are more familiar with West Sumatra as Padang; Minang nomads from West Sumatra are used to introducing themselves as Padang people.

\section{Literature Review}

Ozer (2017) examines city branding means all types of image development studies for a city in order to attract more visitors, raise the quality of life and awareness of the city and provide development etc. Today, the increasing competition among the cities has made city branding a necessity. There are different strategies implemented for city branding. The mostly used strategy among those is the culture-focused branding studies. Culture has a critical importance for city branding and it is used as an international strategy for the economic, social and environmental renovation of cities. Marketing the cultural city sources and activities in an efficient way and branding the city accordingly have become increasingly important. In this chapter, the role and importance of culture which is one of the most important strategies used in city branding has been discussed in detail. Also, the cases of cultural cities which become successfully different from their rivals with their cultural heritage and the strategies implemented in these cases have been analyzed.

https://www.igi-global.com/chapter/the-role-ofculture-in-city-branding/163020 [accessed Sep 13 2018]. B1çakçı (2012) examines aims to go into the cultural reflections of ECoC 2010 Istanbul with a semiological approach, focusing on the extent to which the city is represented through cultural facilities and events. After looking at the historical and socio-political background of Istanbul, official ECoC Web site and programme book of the city are analyzed. Themes, logos, slogans and the content of the programme are questioned from a critical point of view, with the objective of unveiling the symbolic cultural elements in differentiating city brand. What kinds of associations are based on its urban culture and heritages? Furthermore, the study questions if these cultural elements point the public a specific city portrait drawn by an understanding of culture overlapping with the idea of the authorities holding the political power and dominating the current ideology.https://www.jumansciences.com/ojs/inde x.php/IJHS/article/view/2065 [accessed Sep 13 2018].

Kavaratzis (2018) examines culture and entertainment have a major role to play in local economic development. This is exemplified, for instance, in the intense competition between cities to become the cultural capital of Europe, which demands an increased investment. Also the transformation of derelict industrial areas into culture and entertainment districts has been seen all over Europe as a major "method" of regeneration and the means to revitalize local economy. Culture and Entertainment, therefore, have a major role to play in place and city branding as well. A role, that is apparent in the highlight in city promotional material of these new cultural districts, the promise of "exciting" entertainment opportunities, the emphasis on cultural events and festivals and 
cultural "flagship" projects. Especially the organization of small or bigger scale art, sport and other types of events and festivals are seen as instrumental in establishing and reinforcing the place's brand.

https://www.researchgate.net/publication/2555866 32_Branding_the_City_through_Culture_and_Ent ertainment [accessed Sep 13 2018].

Riza (2015) examines city branding strategies are used as a tool to race with other cities by displaying appealing images of the city and its assets. In this context, culture is as a marketable strength and new opportunity for cities to increasingly gain popularity.

https://translate.google.co.id/\#en/id/this\%20paper \%20deals [accessed Sep 13 2018].

Rekettye and Pozsgai (2015) examines The ECC (European Capital of Culture) program which started in 1985 has helped many cities to identify their values and to develop their place branding activities. The study examines how the European Capital of Culture designation of the city helped the marketing activities of the universities located in these cities.

https://hrcak.srce.hr/ojs/index.php/ekonomskivjesnik/article/view/3088 [accessed Sep 13 2018].

\section{Scope of this Research}

This research is a study on Padang City Branding or branding province that considers Padang City included in it: "Padang Your Motherland", "Serenity of Minangkabau", and "Taste of Padang".

\section{The Significance of City Branding}

City branding can be said as a strategy from a country or region to make a strong positioning in the mind of their target market, like the positioning of a product or service, so that the country and region can be widely known throughout the world. Harahap (in Gustiawan, 2011). City branding as image management of Padang City is a strategic innovation of economic, social, commercial, cultural, and regional regulation coordination that is able to make a strong positioning like products or services.

City branding introduces, gives a positive image, attracts tourists and investors, increases trade and wins competition. With this development, various regions in Indonesia are faced with global competition with other regions and cities around the world that cannot be bargained. Padang for example, not only competes with Bali, Jogja, Bandung and Jakarta, but also with Kualalumpur, Singapore, Phuket, Macau and other cities in the world.

Many cities and other countries have felt great profits from getting PAD coffers and APBN revenues from City Branding. Among them are the city of Bandung with "BDG", the city of Jakarta with "Enjoy Jakarta", the city of Solo with "Solo the spirit of Java" and what is even more amazing is the city of Amsterdam - the Netherlands with "I amsterdam" as well as the city of New York - USA with " I Love NY ". Creative City Branding is part of the creative process. Can not just appear instantly, but requires a long process by seeing, thinking, and acting. With this development, various regions in Indonesia are faced with global competition with other regions and cities around the world that cannot be bargained. Padang for example, not only competes with Bali, Jogja, Bandung and Jakarta, but also with Kualalumpur, Singapore, Phuket, Macau and other cities in the world.

Marketing a city, region, and country has become very dynamic, competitive, and important today. In these circumstances, market leaders have portrayed themselves to be more prominent than their competitors. Cities, regions and countries find that a good picture and full implementation of a brand strategy provide many benefits and benefits. Geographical locations, such as products and personal, can also be used as a reference for making a brand by creating and communicating identities for a particular location. Cities, states, and countries today have been actively campaigned through advertising, direct mail, and other communication devices. (Keller, 2003, p. 40).

\section{Problem Statement}

Given the earlier mentioned background, we attempt to establish the problem statement of this study. We phrase it as: To what extend does formulator and maker city branding messages affect the audience consciousness on cultural values?

Referring to the purpose of the study, it can be explained the urgency of this research are as follows: city branding is the City of Padang strategy to make a strong positioning in the minds of their 
target market, like the positioning of a product or service that is widely known throughout the world. The establishment of the Padang City brand is intended to make this city known by the target market (investors, tourist, talent, events) by using icons, slogans, exhibitions, and good positioning, in various forms of media promotion.

City branding is not just a slogan or promotional campaign but a description of the mind, feelings, associations and expectations of one's mind when you see or hear the name of Padang City, its logo, product services, events or various symbols and designs that describe the city of Padang.

The final results of this study are expected to explain city branding communication and provide input that can be applied by the Padang City Government in realizing sustainable tourism and empowering the community. The city of Padang is expected to be able to compile an investment profile and market it through various media with the correct city branding in order to obtain investors with relatively large investment value.

\section{Research question}

1. Three research questions were formulated for the purpose of this study.

What are the dominant cultural values conveyed in Padang City Branding?

2. How city branding promotes the potential of Padang city and the dominant Minangkabau culture adopted by residents of Padang City

3. How do consumers realize that Padang City Branding promotes cities that can be visited and promotes the potential of cities that need investment?

\section{Research Methods}

Two research methods were used to answer these three research questions; they are semiotic analysis and personal interviews with elements of community leaders, academics, business people, government officials, the media, and the community.

\section{Semiotics Analysis}

In general, the rules of study used are qualitative, namely semiotics. In the cultural approach, brands are analyzed as cultural artifacts that move through history (Holt, 2004). In this case the brand is likened to city branding. Huat (2008) examines one of the chief methods that cultural studies use to understand culture is through semiotics. Semiotics is simply the study of signs or words. A semiotic analysis if the images in a magazine ad would look at the different images as if they were words or signs. Saussure believed that semiotics could be used to analyze a large number of „,sign systems", and for this reason, there is no reason why it could not be applied to any media or cultural form (Stokes 2003 in Huat 2008). Semiotics breaks down the content of texts into their component parts and relates them to broader discourses (Stokes 2003 in Huat 2008 ). According to Berger 1987 in Huat (2008), the method involves putting into words how images work by relating them to the ideological structure which organizes meaning.

Judith Williamson"s groundbreaking study of the semiotics of advertising analyses several advertisements taken from women 'es magazines (Williamson 1978 in Huat 2008). Williamson"s work is influenced by an ideological position critical of capitalism, yet the semiotic approach she takes contributes to the development of semiotics today (Stokes 2004).

Avraham and First (2003 in Huat 2008 ) used semiotic analysis to examine how central components of U.S. nation-state/national sphere that are language, flag, political leaders, borders, landscapes, and sights are reflected in Israelie's advertising.

\section{Stage One}

The object of analysis are city brandings of Padang city or a brands that is considered to belong to Padang City, namely "Padang Your Motherland" (2008), "Serenity of Minangkabau" (2017), and "Padang Taste" (2018).

The next stage is to describe the texts, denotatively. At this stage, we look at the setting, poses, colours, cultural artifacts, etc.

Then, we interpret the texts connotatively. This stage allows us to begin to discuss the meanings and implications of each separate sign individually and then collectively. What is the relationship between the linguistic signs and the images? How 
do the two codes of signification work in relation to one another? Does reading the words give you a different interpretation of the images than just looking at the images alone, or are the words reinforcing the images? (Stokes 2003 in Huat 2008).

The next stage is to draw out the cultural codes. How are the images drawing on our cultural knowledge to help us create particular kinds of meaning? Are the cultural codes those one would expect from readers of this particular pool of city branding. Next, we make generalizations about the texts studied. What can we say about the texts studied mean? From there, we move on to make conclusions. Does the analysis confirm my research questions?

\section{Stage Two-Interviews}

According to Stokes (2003 in Huat 2008), semiotic analysis can also combine with participant observations or interviews. For this study, I chose interviews for its relevancy. Total individuals interviewed was 10 . Interviewing offers the opportunity to delve into the everyday worlds of meanings constructed by participants. Through interviews, we can discover very complex social connections and gain insight into the cultural nuances of the participantse ${ }^{\text {ee }}$ world (Morrison et al. 2002).

\section{The Subjects}

All the 10 subjects were Padang people. There were 3 males and 7 females. All interviews were held at the respective subject"s $\mathrm{s}$ home.

\section{Execution of Research}

This was in the form of informal interview where subjects could say anything off the cuff. The interview proper starts when the subjects were asked several structured questions on the city branding . Each interview lasted not more than half hour. Each subject was shown the 3 city branding displayed inside a clear folder. Subjects were given time to browse through the city branding. Then, the subjects were interviewed. The interview starts with a casual chat with the subjects on the topic of "Kota Padangee. Data Analysis

\section{Generalizations from Semiotics Analysis}

If observed, the dominant image of the three city branding is the house roof silhouette of a traditional Minangkabau house known as "rumah gadang", although for the city branding "Serenity of Minangkabau" there is an effort to show images of the atmosphere before peaceful and calm of dawn. The dominant values from the series of advertisements are "tanah kelahiran", "nyaman", "berkesan".

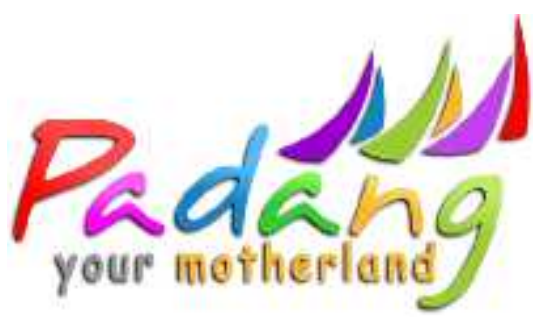

Picture 1. City Branding of "Padang Your Motherland"

Padang City Tourism Brand is a crystallization of the character of the community. With this brand, the City of Padang positions itself as a tourist destination that offers a unique cultural culture in managing people's lives and diversity of customs. As Minang people, the people of Padang City adhere to a matrilineal system, kinship according to maternal lines. This system is unique in the world and only adopted by tribes in China, Indians, Indians, Ghana and the United States. This fact encouraged the Padang City government to create a city branding "Your Motherland". 

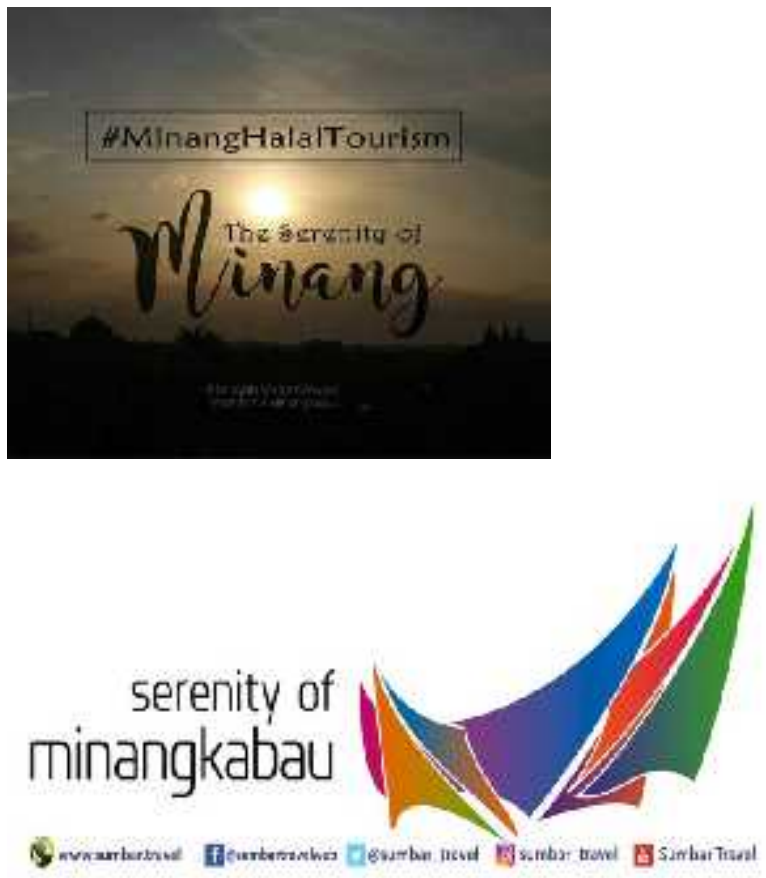

Picture 2. "Serenity of Minangkabau"

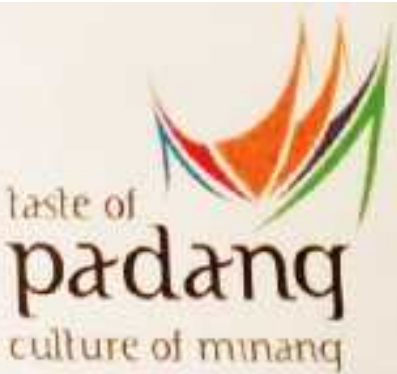

Picture 3. "Padang Taste".

In contrast, "Taste of Padang" which is the branding of the province of West Sumatra is considered by some to not describe the province as a whole and is too narrow. The province's branding is considered to be focused only on Padang City, while West Sumatra has 12 regencies and 7 cities. District and City Government Forums in West Sumatra set "Taste of Padang" as a new name for West Sumatra tourism branding. Budget ceiling for auction is Rp. 2 billion and the tender was won by PT Two Three Four Consultants domiciled in Sleman, DI Yogyakarta. For Padang City the inclusion of the name of this city in the provincial brand is a free promotion.

\section{Data Analysis from Interviews}

The Comments were collected from the subjects. All names of representatives of community elements have been changed. Only important comments are highlighted here. comments are grouped according to their status background.

\section{Community Leader}

However, Minangkabau culture cannot be separated from the residents of Padang City, because Padang is an immigrant area near the inhabitants of West Sumatra who embrace Minangkabau culture, except Mentawai.

\section{Academics}

Not yet in this world, the branding of regions / provinces is represented by only one city. It's just Padang city! This action makes no sense.

\section{Businessman}

Polemic of the pros and cons of naming the city branding of West Sumatra Province ('Taste of Padang) is profit for Padang city beacause free promotion. Another side, The budget of Padang city branding is Rp. 1.6 billion even though it is from the Ministry of Tourism, it is still a waste and does not guarantee an agreement.

\section{Community}

"Diversity is the identity and identity of the nation, but together it does not have to be one color. Each needs to strengthen identity through distinctive colors. The regional government is weak, has no bargaining to the Center. The region itself should determine its city branding, no need to intervene at the center. The branding concerns regional sentiments."

\section{Government}

Determination of city branding, programs, and even financing is central authority.

\section{Media Crew}

City branding if it does not represent its community, is potentially unpopular in its own area. The manufacturing budget is more useful to be transferred to other programs that are more touching the community. The provincial city branding that includes the name of the City of Padang tends to kill other potential cities and districts.

From this study, it is obvious that consumers are aware of the commercial driven-purpose of these 
city branding. Consumers are very much aware of the ,economics of city brandingee, i.e. what is branding certainly has a purpose which benefits the advertiser. In many instances, respondents take an oppositional stand to the advertising messages. They appeared to know the intention of the formulator and maker of "playing with their consciousness" and had thus put up their defenses.

The key to success in carrying out branding goals is how to produce unique and different brand identities and brand identities externally and internally. This is what distinguishes it from product branding that is more concerned with how it is seen and felt externally. The image of this unique destination not only considers external conditions and competition but also finds deeprooted internal and soul uniqueness in the local community.

\section{REFERENCE}

Avraham, E. First, A. 2003. "I buy American": The American image as reflected in Israeli advertising. Journal of Communication, June. 282-299.

Bıçakçı, Ayşe Banu. 2012. Branding the city through culture: Istanbul, European Capital of Culture 2010. Journal of Human Sciences. Vol 9, No 1 (2012) January 1 - June 302012

Holt, Douglas. 2004. How Brand Become Icons: The Principles of Cultural: Branding. Boston, MA: Harvard Business School Press.

Huat. $\mathrm{Ng}$ Chee. Are Advertisements Shaping Our Consciousness? An Analysis Of Selected Chinese New Year Print And Tv Advertisements. Malaysian Journal of Communication. Volume 24 Tahun 2008.

Kavaratzis, M. (2005) Branding the City through Culture and Entertainement. The AESOP 2005 Conference, Vienna, 13-18 July 2005.

Kavaratzis, M. (2005). Hijacking culture: The Disconnection Between Place Culture and Place Brands. The Town Planning Review 86(2):155176 - January 2015

Morrison, M.A., Haley, E., Sheehan, K.B. \& Taylor, R.E. 2002, Using qualitative research in advertising. Strategies, Techniques, and Applications. Thousand Oaks, CA: Sage

Ozer, Selda Uca. 2017. The Role of Culture in City Branding in: Strategic Place Branding Methodologies and Theory for Tourist Attraction: Pages: 18

Rekettye, Gábor and Gyöngyi Pozsgai. 2015. University and place branding: The case of universities located in ECC (European Capital of Culture) cities. Journal Ekonomski-Vjesnik Vol 28 (2015)
Riza, Muge. 2018. Culture and City Branding: Mega-Events and Iconic Buildings as Fragile Means to Brand the City. Journal/PaperInformation. Vol.3 No.7, July 2015. PP. 269-274

Sivaram, S. 1991. Cultural values depicted in Indian television advertising. Gazette 48. 165-176. Star. 2007. 3 April

Stokes, J. 2003. How to do media \& cultural studies. London: Sage.

Williamson, J. 1978. Decoding advertisements. Ideology and Meaning in Advertising. London: Marion Boyars. 